\title{
Effect of Vanadium on Dry matter and Nutrient Concentration in pennyroyal (Mentha pulegium L).
}

\author{
Anastasia AKOUMIANAKI-IOANNIDOU ${ }^{*}$, Pantelis E. BAROUCHAS ${ }^{2}$, Artemis KYRAMARIOU ${ }^{3}$, Evrydiki \\ ILIA $^{3}$, Nikolaos K. MOUSTAKAS ${ }^{3}$ \\ ${ }^{1}$ Floriculture and Landscape Architecture Lab., Agricultural University of Athens, Greece \\ ${ }^{2}$ Lab. of Soil Science and Agricultural Chemistry, Technological Educational Institute of W. Greece. \\ ${ }^{3}$ Soil Science and Agricultural Chemistry Lab. Agricultural University of Athens, Greece \\ *)Corresponding author, e-mail: akouman@aua.gr
}

BulletinUASVM Horticulture 72(2) / 2015

Print ISSN 1843-5254, Electronic ISSN 1843-5394

DOI:10.15835/buasvmcn-hort:11348

\begin{abstract}
An experiment was conducted in pots under greenhouse conditions to study the effects of Vanadium (V) on dry matter and on $\mathrm{V}, \mathrm{Ca}, \mathrm{K}, \mathrm{Mg}, \mathrm{P}, \mathrm{Fe}, \mathrm{Mn}, \mathrm{Ni}, \mathrm{Pd}$, and $\mathrm{Zn}$ concentration in leaves, stems and roots of pennyroyal (Mentha pulegium L.). A completely randomized block design with five $V$ treatments $\left(0,5,10,20,40 \mathrm{mg} \mathrm{L}^{-1}\right)$ and six replications per treatment was laid out. Vanadium was applied to the pot medium (peat soil mixture) as $\mathrm{NH}_{4} \mathrm{VO}_{3}$. No visible toxic or inhibitory symptoms were observed on the plants due to the increasing rates of V. Results indicated that root dry matter increased in plants receiving 10, 20 and $40 \mathrm{mg} \mathrm{V} \mathrm{L}^{-1}$. The vanadium concentration in leaves and stems increased in plants receiving $10 \mathrm{mg} \mathrm{V} \mathrm{L}^{-1}$, and 20 and $40 \mathrm{mg} \mathrm{V} \mathrm{L}^{-1}$, respectively. The vanadium concentration in the leaves was always much lower than in roots and stems indicating that $\mathrm{V}$ accumulated mainly in roots and stems and only small quantities were transferred to the leaves. The results indicated that the $\mathrm{Ca}, \mathrm{K}, \mathrm{Mn}$, and $\mathrm{Zn}$ concentrations in the roots were not affected by $\mathrm{V}$ additions. A reduction of $\mathrm{Ca}, \mathrm{K}, \mathrm{Mg}$, and $\mathrm{Mn}$ concentration was observed in leaves at high $\mathrm{V}$ application rates.
\end{abstract}

Keywords: medicinal herb, culinary herb, pennyroyal.

\section{Introduction}

Vanadium is a transition metal and is widely distributed in the earth's crust with an average concentration of $110 \mathrm{mg} \mathrm{kg}^{-1}$ (Peterson and Girling 1981). The concentration of vanadium in soil depends upon the parent material as well as on the industrial pollution (Who et al., 1987). The fate of vanadium in soils depends on iron and aluminum (hydr)oxides that determines vanadium mobility in soils and waters (Naeem et al., 2007; Wallstedt et al., 2010) The evidence that $\mathrm{V}$ is essential for the growth of higher plants is, however, not yet conclusively demonstrated. It does not meet the criteria of essentiality which set by Arnon and Wessel (1953). Toxicity of vanadium to plants has mainly been studied in nutrient solutions and starts from between $1 \mathrm{mg} \mathrm{V} \mathrm{L}^{-1}$ and
$5 \mathrm{mg} \mathrm{V} \mathrm{L}{ }^{-1}$ for the most sensitive species (Kaplan et al., 1990). Vanadium is toxic to humans at high $\mathrm{V}$ concentrations and can cause irritation of the respiratory tract, although it has not been possible to determine the level of exposure that provokes such effects (Costigan et al., 2001). Several medicinal plants manifest a tendency to take up higher amounts of heavy metals than other plants (Sharma et al., (2011).

\section{Aims and objectives}

Pennyroyal is a herb and up till now we have few information on the response of increasing concentration of vanadium in the soil. The objectives of this research were to examine the effect of $\mathrm{V}$ on dry matter and $\mathrm{V}$ concentration in the plant parts of pennyroyal as well as on the 
concentration of some metals ( $\mathrm{Ca}, \mathrm{K}, \mathrm{Mg}, \mathrm{P}, \mathrm{Fe}, \mathrm{Mn}$, $\mathrm{Ni}, \mathrm{Pd}$, and $\mathrm{Zn}$ ) .

\section{Materials and methods}

Pot experiments were conducted under greenhouseconditionstostudy theeffectofdifferent $\mathrm{V}$ applications in pennyroyal. Seedlings growth in individual pots with a substrate consisting of $50 \%$ peat and $50 \%$ perlite by volume (1:1), with $\mathrm{pH} 5.6$, organic matter content 90\%-95\% and Electrical Conductivity $0.3 \mathrm{~S} / \mathrm{m}$. A completely randomized block were design with five $V$ treatments $(0,5,10$, 20, $40 \mathrm{mg} \mathrm{L}^{-1}$ ) and six replications per treatment was laid out. Vanadium was applied as ammonium metavanadate $\left(\mathrm{NH}_{4} \mathrm{VO}_{3}\right.$ ) (total $500 \mathrm{~mL}$ per pot of each treatment for the whole cultivation period). At the end of the experiment, leaves, stems and roots were harvested and were oven-dried at $50^{\circ} \mathrm{C}$ to constant weight, ground in a stainless steel Wiley mill and passed through a $250 \mu \mathrm{m}$ plastic sieve. $0.5 \mathrm{~g}$ of plant parts smaller than $250 \mu \mathrm{m}$ in diameter from each pot were placed in beakers and ashed at $450^{\circ} \mathrm{C}$. The residue was dissolved in 5 $\mathrm{ml}$ of $6 \mathrm{~N} \mathrm{HCl}$ (Miller RO, 1998). The clear solutions were analyzed by ICP-OES (Thermo Scientific iCAP 6000). The influence of $V$ application on dry matter and $\mathrm{V}, \mathrm{Ca}, \mathrm{K}, \mathrm{Mg}, \mathrm{P}, \mathrm{Fe}, \mathrm{Mn}, \mathrm{Ni}, \mathrm{Pd}$, and $\mathrm{Zn}$ concentration in the plant parts of pennyroyal was evaluated by analysis of variance (ANOVA). Where a significant difference was found, the Duncan's Multiple Range Test at the 5\% level of probability was used to compare individual treatment means.

\section{Results and Discussion}

No visible toxic symptoms or inhibitory effects were observed in the plants due to increasing applications of $\mathrm{V}$ during the experiment. Leaves, stems and root dry matter increased with increasing rates of $\mathrm{V}$ (Tab. 1, 2, 3). The $\mathrm{V}$ concentration in the leaves of the control ranged from 0.31 to $3.08 \mathrm{mg} \mathrm{kg}^{-1}$ dry weight (DW) and did not differ significantly from that in the treatments with 5, 10, $20 \mathrm{mg} \mathrm{L}^{-1} \mathrm{~V}$. However, the plants that received $40 \mathrm{mg} \mathrm{L}^{-1} \mathrm{~V}$ showed significantly higher concentrations of this metal in the leaves (Table 1). The $\mathrm{Mn}, \mathrm{Ca}, \mathrm{K}$, and $\mathrm{Mg}$ content of the leaves decreased with increasing rates of $\mathrm{V}$, but $\mathrm{Pb}$ and Zn content were not affected.

Tab. 1. Effect of $\mathrm{V}$ on leaves leaf dry matter (LDM) and on $\mathrm{V}, \mathrm{Fe}, \mathrm{Mn}, \mathrm{Pb}, \mathrm{Zn}, \mathrm{Ca}$, K, and $\mathrm{Mg}$ concentrations in the leaves of Pennyroyal.

\begin{tabular}{|c|c|c|c|c|c|c|c|c|c|c|c|c|c|c|c|c|c|c|}
\hline V added & LDM & & V & & $\mathrm{Fe}$ & & $\mathrm{Mn}$ & & $\mathrm{Pb}$ & & $\mathrm{Zn}$ & & $\mathrm{Ca}$ & & $\mathrm{K}$ & & $\mathrm{Mg}$ & \\
\hline $\mathrm{mg} \mathrm{L}^{-1}$ & g pla & & & & & & $\mathrm{mg} \mathrm{k}$ & $g^{-1}$ & & & & & & & $\%$ & & & \\
\hline 0 & 0.88 & $\mathrm{~b}$ & 0.31 & $a$ & 1.74 & $\mathrm{a}$ & 4.72 & $\mathrm{~b}$ & 2.00 & $\mathrm{a}$ & 8.60 & $a$ & 0.42 & c & 0.51 & $\mathrm{~b}$ & 0.04 & $\mathrm{~b}$ \\
\hline 5 & 0.91 & bc & 0.41 & $\mathrm{a}$ & 1.83 & $\mathrm{a}$ & 4.85 & $\mathrm{~b}$ & 1.72 & $\mathrm{ab}$ & 8.66 & $\mathrm{a}$ & 0.41 & c & 0.63 & c & 0.04 & $\mathrm{~b}$ \\
\hline 10 & 1.07 & ac & 0.41 & $\mathrm{a}$ & 1.03 & $\mathrm{~b}$ & 2.03 & $\mathrm{a}$ & 1.76 & $\mathrm{ab}$ & 7.19 & $\mathrm{ab}$ & 0.31 & $\mathrm{~b}$ & 0.34 & $\mathrm{a}$ & 0.02 & $\mathrm{a}$ \\
\hline 20 & 1.14 & $\mathrm{ac}$ & 0.34 & $a$ & 2.52 & $\mathrm{c}$ & 1.68 & $\mathrm{a}$ & 1.36 & $\mathrm{a}$ & 8.04 & $\mathrm{a}$ & 0.23 & $a b$ & 0.33 & $a$ & 0.02 & $a$ \\
\hline 40 & 1.14 & $\mathrm{ac}$ & 3.08 & $\mathrm{~b}$ & 1.65 & $\mathrm{a}$ & 1.66 & $\mathrm{a}$ & 1.27 & $\mathrm{a}$ & 6.18 & $\mathrm{~b}$ & 0.21 & $\mathrm{ab}$ & 0.28 & $\mathrm{a}$ & 0.01 & $\bar{a}$ \\
\hline
\end{tabular}

Tab. 2. Effect of $\mathrm{V}$ on stems dry matter (SDM) and on $\mathrm{V}, \mathrm{Fe}, \mathrm{Mn}, \mathrm{Pb}, \mathrm{Zn}, \mathrm{Ca}, \mathrm{K}$, and $\mathrm{Mg}$ concentrations in the stems of Pennyroyal.

\begin{tabular}{|c|c|c|c|c|c|c|c|c|c|c|c|c|c|c|c|c|}
\hline $\mathrm{V}$ added & SDM & $\mathrm{V}$ & & $\mathrm{Fe}$ & & $\mathrm{Mn}$ & & $\mathrm{Pb}$ & & $\mathrm{Zn}$ & & $\mathrm{Ca}$ & & $\mathrm{K}$ & & $\mathrm{Mg}$ \\
\hline $\mathrm{mg} \mathrm{L}^{-1}$ & g plant $^{-1}$ & & & & & $\mathrm{mg} \mathrm{kg}$ & & & & & & & & $\%$ & & \\
\hline 0 & 0.87 & 0.35 & $\mathrm{a}$ & 45.89 & $\mathrm{C}$ & 11.57 & $\mathrm{bc}$ & 6.54 & $\mathrm{~b}$ & 10.53 & $\mathrm{~b}$ & 0.58 & $\mathrm{~b}$ & 1.51 & $\mathrm{a}$ & $0.05 \mathrm{ab}$ \\
\hline 5 & $0.91 \mathrm{ab}$ & 3.11 & $\mathrm{~b}$ & 48.85 & $\mathrm{C}$ & 14.00 & c & 7.45 & $\mathrm{~b}$ & 10.65 & $\mathrm{~b}$ & 0.57 & $\mathrm{~b}$ & 1.60 & $\mathrm{a}$ & 0.06 \\
\hline 10 & $1.00 \mathrm{ab}$ & 3.97 & $\mathrm{~b}$ & 28.81 & $\mathrm{~b}$ & 10.98 & $\mathrm{ab}$ & 3.08 & $\mathrm{a}$ & 6.84 & $\mathrm{a}$ & 0.46 & $\mathrm{a}$ & 1.57 & $\mathrm{a}$ & $0.05 \mathrm{ab}$ \\
\hline 20 & $1.12 \quad b$ & 6.63 & $\mathrm{C}$ & 20.07 & $\mathrm{a}$ & 8.53 & $a b$ & 2.01 & $\mathrm{a}$ & 5.87 & $\mathrm{a}$ & 0.40 & $\mathrm{a}$ & 1.31 & $\mathrm{a}$ & $0.04 \quad \mathrm{ab}$ \\
\hline 40 & $1.03 \mathrm{ab}$ & 8.93 & $\mathrm{~d}$ & 21.56 & $\mathrm{ab}$ & 10.17 & $a b$ & 2.89 & $\mathrm{a}$ & 5.82 & $\mathrm{a}$ & 0.39 & $\mathrm{a}$ & 1.29 & $\mathrm{a}$ & $0.04 \mathrm{ab}$ \\
\hline
\end{tabular}


Tab. 3. Effect of $\mathrm{V}$ on root dry matter (RDM) and on $\mathrm{V}, \mathrm{Fe}, \mathrm{Mn}, \mathrm{Pb}, \mathrm{Zn}, \mathrm{Ca}, \mathrm{K}$, and $\mathrm{Mg}$ concentrations in the roots of Pennyroyal

\begin{tabular}{|c|c|c|c|c|c|c|c|c|c|c|c|c|c|c|c|c|c|c|}
\hline \multirow{2}{*}{$\begin{array}{c}\text { V added } \\
\mathrm{mg} \mathrm{L}^{-1} \\
\end{array}$} & \multirow{2}{*}{\multicolumn{2}{|c|}{ g plant $^{-1}$}} & $\mathrm{~V}$ & & $\mathrm{Fe}$ & & $\mathrm{Mn}$ & & $\mathrm{Pb}$ & & $\mathrm{Zn}$ & & $\mathrm{Ca}$ & & $\mathrm{K}$ & & $\mathrm{Mg}$ & \\
\hline & & & \multicolumn{10}{|c|}{$\mathrm{mg} \mathrm{kg}^{-1}$} & \multicolumn{6}{|c|}{$\%$} \\
\hline 0 & 0.24 & $\mathrm{a}$ & 0.49 & $\mathrm{a}$ & 59.16 & $\mathrm{a}$ & 5.19 & $\mathrm{a}$ & 3.46 & $\mathrm{c}$ & 13.84 & $\mathrm{a}$ & 0.49 & $\mathrm{a}$ & 0.47 & $\mathrm{a}$ & 0.15 & $\mathrm{a}$ \\
\hline 5 & 0.23 & $\mathrm{a}$ & 4.65 & $\mathrm{~b}$ & 68.14 & $a b$ & 5.70 & $\mathrm{a}$ & 2.94 & $\mathrm{bc}$ & 15.12 & $\mathrm{a}$ & 0.51 & $\mathrm{a}$ & 0.39 & $\mathrm{a}$ & 0.14 & $\mathrm{a}$ \\
\hline 10 & 0.35 & $\mathrm{~b}$ & 7.04 & $\mathrm{c}$ & 74.02 & $\mathrm{~b}$ & 6.10 & $\mathrm{a}$ & 2.66 & $\mathrm{ab}$ & 14.59 & $\mathrm{a}$ & 0.52 & $\mathrm{a}$ & 0.47 & $\mathrm{a}$ & 0.17 & $a b$ \\
\hline 20 & 0.50 & $\mathrm{c}$ & 11.37 & $\mathrm{~d}$ & 89.33 & $\mathrm{c}$ & 6.84 & $\mathrm{a}$ & 2.11 & $\mathrm{ab}$ & 11.72 & $\mathrm{a}$ & 0.54 & $\mathrm{a}$ & 0.37 & $\mathrm{a}$ & 0.18 & $\mathrm{~b}$ \\
\hline 40 & 0.55 & $\mathrm{c}$ & 26.00 & $\mathrm{e}$ & 96.00 & $\mathrm{c}$ & 6.88 & $\mathrm{a}$ & 2.11 & $\mathrm{ab}$ & 13.97 & $\mathrm{a}$ & 0.55 & $\mathrm{a}$ & 0.40 & $\mathrm{a}$ & 0.16 & $a b$ \\
\hline
\end{tabular}

Column means followed by the same letter are not significantly different, according to Duncan's test, at $\mathrm{p}<0.05$

column means without letters indicate no significance by Duncan's test at $\mathrm{p} \leq 0.05 ;{ }^{*} \mathrm{p} \leq 0.05$

Vanadium concentrations in the stems of the control ranged from 0.35 to $8.93 \mathrm{mg} \mathrm{kg}-1$ (DW) and increased significantly with increasing rates of $\mathrm{V}$ (Tab. 2). $\mathrm{Zn}, \mathrm{Pb}$, and Ca concentrations in the stems decreased significantly with increasing rates of $\mathrm{V}$, in opposite $\mathrm{Mn}, \mathrm{Mg}$ and $\mathrm{K}$ were not affected by $\mathrm{V}$.

Vanadium concentrations in the roots of the control ranged from 0.49 to $26.0 \mathrm{mg} \mathrm{kg}^{-1}$ (DW) and increased significantly with increasing rates of $\mathrm{V}$ (Tab. 3).

We wish to emphasize that the plants grown in pots with $40 \mathrm{mg} \mathrm{L}^{-1} \mathrm{~V}$ accumulated 53 times more $\mathrm{V}$ in the roots than those in the control vanadium. Saco et al. (2013) found that the leaf content of $V$ in Phaseolus vulgaris was always much lower than in the roots. The observation that $\mathrm{V}$ accumulated in great amounts in the roots supports the existence of a mechanism that favors $V$ retention by the roots, but this has not been identified to date. Peterson and Girling (1981), reported that V precipitated in the roots as calcium vanadate, whereas Morrell et al. (1986) concluded that $\mathrm{V}$ accumulated due to the reduction of vanadate (V) to vanadyl (IV) during root uptake, which decreased further translocation within the plant. However, Kaplan et al. (1990) considered that $\mathrm{V}$ accumulated as a result of the formation of complexes with organic compounds, such as organic acids and amino acids. Immobilization of $\mathrm{V}$ in the roots is presumed to be the primary mechanism by which plants tolerate large quantities of $\mathrm{V}$ in the soil. The iron concentration in leaves and stems decreased significantly with increasing rates of $\mathrm{V}$, in opposite Fe concentration in roots increased with increasing rates of vanadium. Kaplan et al. (1990) reported that the Fe content in the aerial plant parts of beans increased with increasing rates of $\mathrm{V}$. $\mathrm{Mn}, \mathrm{Zn}, \mathrm{Ca}$, and $\mathrm{K}$ concentration in roots of pennyroyal were not affected by $\mathrm{V}$ additions, but $\mathrm{Pb}$ and $\mathrm{Mg}$ content decreased with increasing rates of $\mathrm{V}$.

\section{Conclusion}

Our study indicates that $\mathrm{V}$ accumulated mainly in the roots and secondarily in the stems in pennyroyal. Iron $(\mathrm{Fe})$ concentrations follows the same pattern as $\mathrm{V}$.

\section{REFERENCES}

1. Arnon DI, Wessel G (1953). Vanadium as essential element for green plants. Nature. 172: 1039-1040.

2. Costigan M, Cary R, Dobson S (2001). Vanadium pentoxide and other inorganic vanadium compounds. In Concise International Chemical Assessment Document 29.

3. Kaplan DI, Adriano DC, Carlson CL, Sajwan KS (1990). Vanadium toxicity and accumulation by beans. Water Air Soil Poll. 49: 81-91.

4. Naeem A, Westerhoff P, Mustafa S (2007). Vanadium removal by metal (hydr)oxide adsorbents. Water Res. 41:1596-1602.

5. Miller RO (1998) Dry ashing. In Karla YR.ed. Handbook of reference methods for plant analysis. Boca Roton, Boston, New York: CRC press.

6. Morrell BG, Lepp NW, Phips DA (1986). Vanadium uptake by higher plants: some recent development. Envir. Geochemistry and Helth. 8: 14-48.

7. Peterson PJ, Girling CA (1981). Vanadium. In: Lepp NW. ed. Effect of Heavy Metal Pollution on Plants, London, New Jersey: Applied Science Publishers.

8. Saco D, Martin S, San Jose P (2013). Vanadium distribution in roots and leaves of Phaseolus vulgaris: morphological and ultrastructural effects. Biologia Plantarum. 57: 128132.

9. Sarma H, Deka S, Deka H, Saikia RR (2011). Accumulation of heavy metals in selected medicinal plants. Rev Environ Contam Toxicol. 214: 63-86. 
10. Who (1987). Air quality guidelines for Europe. Copenhagen. World Health Organization. Regional Office for Europe: 426.
11. Wallstedt T, Bjorkvald L, Gustafsson JP (2010). Increasing concentrations of arsenic and vanadium in (southern) Swedish streams. Appl Geochem. 25:1162-1175. 